\title{
CONTRACTUAL VERSUS NON-CONTRACTUAL TRADE: THE ROLE OF INSTITUTIONS IN CHINA
}

\author{
Robert C. Feenstra \\ Chang Hong \\ Hong Ma \\ Barbara J. Spencer \\ Working Paper 17728 \\ http://www.nber.org/papers/w17728 \\ NATIONAL BUREAU OF ECONOMIC RESEARCH \\ 1050 Massachusetts Avenue \\ Cambridge, MA 02138 \\ January 2012
}

The authors thank Nathan Nunn for helpful discussions and Greg Wright for research assistance. We also thank the National Science Foundation and the Social Sciences and Humanities Research Council of Canada for financial support. The views expressed herein are those of the authors and do not necessarily reflect the views of the National Bureau of Economic Research.

NBER working papers are circulated for discussion and comment purposes. They have not been peerreviewed or been subject to the review by the NBER Board of Directors that accompanies official NBER publications.

(C) 2012 by Robert C. Feenstra, Chang Hong, Hong Ma, and Barbara J. Spencer. All rights reserved. Short sections of text, not to exceed two paragraphs, may be quoted without explicit permission provided that full credit, including $(\odot)$ notice, is given to the source. 
Contractual Versus Non-Contractual Trade: The Role of Institutions in China

Robert C. Feenstra, Chang Hong, Hong Ma, and Barbara J. Spencer

NBER Working Paper No. 17728

January 2012

JEL No. F13

\section{ABSTRACT}

Recent research has demonstrated the importance of institutional quality at the country level for both the volume of trade and the ability to trade in differentiated goods that rely on contract enforcement. This paper takes advantage of cross-provincial variation in institutional quality in China, and export data that distinguishes between foreign and domestic exporters and processing versus ordinary trade, to show that institutional quality is a significant factor in determining Chinese provincial export patterns. Institutions matter more for processing trade, and more for foreign firms, just as we would expect from a greater reliance on contracts in these cases.

Robert C. Feenstra

Department of Economics

University of California, Davis

One Shields Avenue

Davis, CA 95616

and NBER

rcfeenstra@ucdavis.edu

Chang Hong

Department of Economics

Clark University

Worcester, MA 01610

CHong@clarku.edu
Hong Ma

Tsinghua University

Department of Economics

Beijing, China

mahong@sem.tsinghua.edu.cn

Barbara J. Spencer

University of British Columbia

Sauder School of Business

2053 Main Mall

Vancouver, BC V6T $1 Z 2$

CANADA

and NBER

barbara.spencer@sauder.ubc.ca 


\section{Introduction}

The importance of institutional quality in determining the volume of trade has been established by several recent papers (Levchenko, 2007, Nunn, 2007, Ranjan and Lee , 2007). ${ }^{1}$ Beyond its influence on the volume of trade, however, institutional quality can also have an impact on the organization of trade and production. Levchenko (2007) shows that countries with better institutions specialize in goods that are institutionally dependent, as measured by the Herfindahl index of intermediate inputs, while Ranjan and Lee (2007) investigate the different effects of contract enforcement on homogeneous goods versus differentiated goods. Combining these two approaches, Nunn (2007) measures the extent of differentiation in intermediate inputs, arguing that goods which rely on more differentiated inputs will be more subject to "hold up" problems with suppliers, and therefore benefit more from good institutions. The index he constructs is a measure of the contract intensity of exports.

The above papers all focus on either U.S. imports or world trade data, and do not distinguish regions within countries. But institutions certainly differ a great deal within countries (Acemoglu and Dell, 2009). In the current paper, we take advantage of the cross-province variation in institutional quality in a large developing country, namely China, to examine the significance of institutional quality for Chinese export patterns. The tremendous growth in exports from China, especially since it joined the WTO in 2001, is reason enough to direct attention to that country. But in addition, provincial imports and exports from China are separated into categories not typically available. Consequently, we are able to address the limitation of previous research that it uses only indirect measures, such as the Herfindahl index

\footnotetext{
${ }^{1}$ The importance of institutions has also been particularly emphasized by the empirical work by La Porta, Lopez-deSilanes, Shleifer and Vishny (1997, 1998), and Acemoglu, Johnson and Robinson (2001, 2002). In our working paper (Feenstra and Spencer, 2005), we also argue that local institutional differences play a significant role in the pattern of exports depending on their contractual relations.
} 
of intermediate inputs or the Nunn index of contractual intensity, to characterize the extent to which traded goods rely on contracts.

Chinese trade data is separated into “ordinary” exports and a special customs designation, called processing exports. As their name suggests, processing exports are goods that rely on inputs that are imported duty free, then processed in China, with the finished good exported. Such relationships are contractual in the sense that the buyer specifies the characteristics of the good and makes payment accordingly. In contrast, “ordinary” imports and exports have no special customs treatment and we treat them as closer to arms-length transactions. Moreover, the Chinese trade data also categorize the ownership of importing and exporting firms as domestic, joint venture or foreign and it seems reasonable to expect foreign firms to be more dependent on contracts and therefore on institutions. Du et al (2010), for example, find that provinces in China that have stronger public institutions tend to attract more foreign investment. So the trade data are broken down into categories that arguably are related to the use of contracts. To reflect this idea, we refer to the categories of ownership and the choice between processing and ordinary exports as contractual modes of exports.

It is no accident that institutional authority differs across provinces. The old Chinese proverb, “The mountains are high and the emperor is far away,” is suggestive of a neglect of authority in regions far away from Beijing, as was exacerbated by colonial rule that differed across regions. For institutional quality, we use measures of the quality of the judicial system in enforcing contracts for 30 provincial capital cities in China from the World Bank (2008). Since colonial rule is exogenous, it provides a useful instrument for our court-based measures of institutional quality. Combining this institutional variation with the contractual relations in the trade data makes China an excellent testing ground for the impact of institutions on trade. 
For the empirical analysis, we provide an initial interaction of the contractual mode of exports (varies by ownership and processing versus ordinary trade) with the institutional quality of the court system (both with and without instrumentation by Colonial status). To remove the potential role of geography as an omitted factor, we add a three-way interaction term by constructing the index of contractual intensity from Nunn (2007) and combining it with contractual mode and institutional quality. For each of our court measures (instrumented by colonial status) and contractual modes, this three-way interaction is statistically and economically significant in explaining the volume of trade. Admittedly, the variation in province-industry-year export values that are explained by this triple interaction is not that large: about $2-3 \%$ of the total variation, but this is very similar to what Nunn (2007) finds for the explanatory power of his index when applied across countries. Here, we find similar results within a country. Furthermore, we find a very systematic pattern to the impact of institutional quality: institutions matter more for processing trade than ordinary trade, and more for foreign firms, just as we would expect from a greater reliance on contracts in both cases.

We examine exports from China from 1997-2008, which includes China’s accession to the WTO in 2001. A cursory look at the data shows that the growth in processing trade by foreign-owned firms has been particularly strong since 2001. One explanation for this growth is that China opened numerous EPZs (export processing zones) since 2001. We investigate the extent to which these zones act as a substitute or a complement for institutional quality; that is, whether strong courts reinforce the impact of EPZs or whether these zones substitute for court authority. We find support for the latter hypothesis, and that the growth of EPZs since 2001 explain a further $0.5-1 \%$ of the variation in province-industry-year export values. 
In the next section we briefly describe the Chinese trade and institutional data, specify our formulation of the Nunn (2007) index of contract intensity, which we construct using the Chinese input-output table, and undertake some preliminary analysis. Section 3 develops the regression specification and then considers some initial results concerning the impact on the value of exports of institutional quality interacted with the various contractual modes determined by ownership and the type of trade. Section 4 adds the three way interaction of the Nunn (2007) index with institutional quality and contractual mode to the analysis of section 3 . The results of section 4 are further extended in section 5 to allow for the EPZs, and section 6 concludes.

\section{Chinese Trade and Institutional Data}

Data for Chinese exports and imports are available at the Harmonized System (HS) of product classification, broken down by source or destination countries, city of origin or destination, customs regime (including both ordinary and processing trade), and ownership of firm. ${ }^{2}$ Table 1 shows a simple decomposition of different types of exports. Processing export plays a major role, accounting for over 54 percent of China’s total exports over our sample period from 1997 to 2008. The share of foreign firms ${ }^{3}$ in exports increases drastically from around one-third in 1997 to over 54 percent of the total value of exports in 2008. These firms are especially important in processing trade, as shown in column (3).

Processing trade has been further broken into two types, as follows: ${ }^{4}$

\footnotetext{
${ }^{2}$ These data are purchased from Mr. George Chen, China Customs Statistics Information Center, Economics Information Agency, Hong Kong; EIAET@PACIFIC.NET.HK. Several researchers are now using Chinese firmlevel import and export data (see Ahn, et al, 2010; Manova and Zhang, 2009) obtained from the same source.

${ }^{3}$ Two types of foreign firms are recognized by the Chinese government: wholly foreign-owned enterprises and equity joint ventures in which a foreign interest has at least a 25 percent ownership stake. We include both these categories in our measure of foreign firms' exports.

${ }^{4}$ In Chinese trade statistics, pure-assembly is called "processing and assembling" or "processing with supplied materials," and the import-and-assembly arrangement is called "processing with imported materials." The following description of these types draws on Feenstra and Hanson (2005).
} 
The Pure-Assembly Regime. In this arrangement, a foreign firm supplies a factory in China, which can be foreign-owned or domestic, with materials from abroad (Naughton, 1996). While the factory takes possession of the imported materials during processing, the foreign firm retains ownership over them. The foreign firm pays the factory in China a fee for its processing services. To obtain clearance from Chinese customs to import materials and to export processed goods, the terms of the transaction between the Chinese factory and the foreign firm must be stipulated in a written contract and presented in advance to Chinese customs officials for approval. Legally, the processing factory may use imported materials for the sole purpose of meeting its obligations to the foreign client.

The Import-and-Assembly Regime. In this arrangement, the processing factory in China (foreign or domestic) plays a more active role. Column (4) of Table 1 shows that this regime is the more common form of export processing and its share is on the rise during the last decade. Its share of total processing exports increases to over 80 percent, from 70 percent in 1997. Different from the pure-assembly regime, under the import-and-assembly arrangement, the factory imports materials of its own accord and takes ownership of these materials during processing. The factory may process goods for multiple foreign firms (World Bank 1994) and thus may also control the export of processed goods. The factory would still require export contracts to obtain the "processing" designation that authorizes the duty-free import of materials.

In the last two columns of Table 1 we show the number of export processing zones (EPZ) within China and the proportion of total Chinese exports from these zones. Since the early 1980s, China has had Special Economic Zones devoted to exports, primarily in coastal cities. ${ }^{5}$ Based on the successful experience with these zones, beginning in 1985 they were expanded to inland

\footnotetext{
${ }^{5}$ The Special Economic Zones started with Shantou, Shenzhen, Zhuhai in Guangdong province, Xiamen in Fujian province, and the entire island of Hainan, and were expanded in 1984 to include fourteen other coastal cities
} 
areas and called Economic and Technological Development Zones; many of these zones exist. The EPZs must be established within the confines of these latter zones, but were newly developed in response to China's accession to the WTO in 2001. ${ }^{6}$ As a requirement of accession, China agreed to more fully regulate processing trade, which is done by focusing it within these zones. Export processing within the zones enjoy various advantages such as duty-free imports (and not having to temporarily post bonds for tariffs on these imports until they are processed into exports); no import quotas; no taxes on utilities; a preferential corporate tax of $15 \%$, etc. First approved at the end of 2000, there were fifty active EPZs as of 2008, as shown in column (5). ${ }^{7}$ Many provinces enjoy these zones, with the largest number found in Jiangsu province (13 in 2008), followed by Shanghai (7) and Shangdong (5).

The final column of Table 1 shows that processing exports from EPZ accounted for $0.1 \%$ of total Chinese exports in 2001 and $7.1 \%$ in 2008. This substantial growth occurred at a time when the share of overall processing exports in total exports was falling in China; see column (1). It would be incorrect to say that the EPZs caused this growth in processing exports, since much of it could have been diverted from other zones. Nevertheless, we view the EPZs as a significant institutional innovation in China, precipitated by its accession to the WTO, and will investigate its impacts.

For our main measures of institutional quality, we use indexes of judicial quality from the World Bank (2008). These indexes are based on the methodology developed in Djankow et al (2002), and measure the quality of the judicial system in enforcing contracts for 30 provincial capitals in China. There are three indicators of quality: (i) a ranking of the efficiency of the court

\footnotetext{
${ }^{6}$ While the EPZs were started in 2001, they can be viewed as an extension of Bonded Areas that were set up earlier (15 Bonded Areas were established from 1987 to 1996, at which time the State Council stopped their approval). The Bonded Areas were intended to facilitate processing trade, but had fewer of the advantages that EPZs enjoy.

7 The number of zones shown in Table 1 are computed from our Chinese export data, and are smaller than the number of zones that are approved (58 since 2005) but do not yet show any exports.
} 
system in each provincial capital city, or "court rank"; (ii) the number of days from the time the plaintiff files the lawsuit until the time of payment, or "court time"; (iii) the official cost of going through court procedure, or “court cost”. Summary statistics for the institutional quality variables for southeastern coastal provinces and for interior and northern provinces are show in Table $2 .^{8}$ Overall, institutions in the inland and northern provinces are not as efficient as the coastal counterparts. The quality of the court system is likely to be endogenous to the amount of trade. To control for this, we follow Lu et al (2008) in using former colonial rule - by Britain, France, Russia, or several of these - as well as provincial population in 1953 as instruments. ${ }^{9}$ We expect that former colonies will have better judicial quality.

We use the Nunn (2007) measure of the “contract intensity” of goods or relationshipspecificity of goods, which is based on the differentiation of intermediate inputs as in Rauch (1999). ${ }^{10}$ Two measures of contract intensity are constructed as:

$$
z_{i}^{1}=\sum_{j} \theta_{i j} R_{j}^{\text {diff }} \quad \text { and } \quad z_{i}^{2}=\sum_{j} \theta_{i j}\left(R_{j}^{\text {diff }}+R_{j}^{\text {refprice }}\right),
$$

where $\theta_{i j}$ is the share of input $j$ used in industry $i$; $R_{j}^{\text {diff }}$ is the proportion of input $j$ that are differentiated; and $R_{j}^{\text {refprice }}$ is the proportion of input $j$ that is not sold on an exchange but are reference priced. Both contract intensity measures classify the proportion of inputs that are relationship-specific, but the second measure $z_{i}^{2}$ is more broadly defined as it also includes reference-priced inputs as being relationship-specific. We refer to $z_{i}^{1}$ and $z_{i}^{2}$ as the narrow and

\footnotetext{
${ }^{8}$ We make a simple adjustment to the scale of these variables so that a higher value indicates better institutional quality; see the notes to Table 2.

${ }^{9}$ Britain colonies are: Guizhou, Sichuan, Hubei, Hunan, Jiangxi, Anhui, Jiangsu, Henan, Zhejiang, Chongqing; French colonies are: Yunnan, Hainan, Guangxi, Guangdong; Russian colonies are: Xinjiang, Neimenggu, Heilongjiang, Liaoning, Jilin; and multi-occupancy colonies are: Shanghai, Tianjin. No foreign occupancy consist of Gansu, Beijing, Hebei, Ningxia, Qinghai, Shan'xi, and Shanxi.

${ }_{10}$ The Rauch (1999) index has both a liberal and a conservative estimate for product classification, which differ in the criterion used to classify goods as reference priced or differentiated. We used both estimates for our estimation and obtained similar results, but here report estimates using the conservative classification.
} 
broad Nunn measures. In general, $z_{i}^{n}$ index ranges between 0 and 1 and the larger the index value, the more contract dependent that industry is.

One feature of the contract intensity variable that distinguishes it from Nunn (2007) is that the Chinese input-output table provides several sets of weights to use for $\theta_{i j}$ : those obtained from domestic or imported inputs going to either domestic output or exports. We use the weights most appropriate to the trade flow in question, so for processing trade we use the weights for imported intermediate inputs rather than domestic inputs. ${ }^{11}$ The input-output table distinguishes 22 traded industries that are used to measure exports, and also provides the labor and capital used per yuan value of exports, which we denote by $\ell_{i}$ and $k_{i}$, the labor and capital intensity of each industry $i$. These factor intensities differ between processing exports and ordinary exports. We supplemented the factor intensities with measures of skilled labor and capital endowments by province $r$ in year t, or $L_{t}^{r}$ and $K_{t}^{r}$. The variable $L_{t}^{r}$ measures the educational attainment of the provincial workforce. ${ }^{12}$ The provincial capital endowments $K_{t}^{r}$ are obtained from Bai, Hsieh and Qian (2006). ${ }^{13}$ In our regressions we follow Nunn (2007) in using $L_{t}^{r} \ell_{i}$ and $K_{t}^{r} k_{i}$ as the interactions between factor endowments and industry intensities, which we refer to as "skill*labor intensity” and "capital*capital intensity."

A preliminary regression is provided in Table 3, where province-year exports are distinguished according to the Rauch classification of differentiated, reference-priced, and homogeneous goods, with the last category omitted. The value of exports is summed within these

\footnotetext{
${ }^{11}$ We also experimented with using domestic inputs for both ordinary and processing exports, and the results turned out to be the same qualitatively.

${ }^{12}$ Using data from various years of China Statistical Yearbook, we ran a preliminary regression of provincial average manufacturing wages on the fraction of the population with primary, junior, senior and university education. The predicted wage from this regression is used as the skilled labor endowment.

${ }^{13}$ We are grateful to Chong-En Bai for generously providing us the data on Chinese provincial capital stock.
} 
three categories across 30 provinces and 11 years, giving 990 observations. ${ }^{14}$ Indicator variables for differentiated and reference-priced exports are interacted with institution quality.

The first three columns in Table 3 are run with OLS, and the next three use colonial rule as an instrumental variable for institutional quality. According to all our measures, better institutional quality is significant in raising the exports of differentiated goods. In all but one case, better institutional quality also raises the exports of reference-priced goods, but with coefficients that are about one-third as large. To be more specific, our IV estimates with court rank as the measure of institutional quality imply that moving up one rank increases exports in differentiated goods by 10.5 percent, and increases exports in reference-priced goods by 3.1 percent, relative to exports of homogeneous products. For example, let us compare the inland province Sichuan (ranked $23^{\text {rd }}$ ) with the coastal Shanghai (ranked $\left.4{ }^{\text {th }}\right) .{ }^{15}$ If Sichuan achieved the same institutional quality level as Shanghai, ceteris paribus, then Sichuan's exports of differentiated goods would increase by $\exp [(23-4) \times 0.105]=7.4$ times and its exports of reference-priced goods would nearly double. ${ }^{16}$

We test for weak instruments using an F-test on the instruments in the first-stage regression, as recommend by Stock et al (2002). The variables court ranking and court cost have F-test of 109 and 79, respectively, indicated that these instruments are not weak. But court time has an F-test of only 8, which is below the Stock-Yogo criterion of 10, so we conclude that the court time instrument is weak and there is a potential for bias in the IV results. One reason for

\footnotetext{
14 In later regressions we are missing provincial endowment data for 2008, so for consistency, we have omitted that year from all regressions reported.

${ }^{15}$ We also calculated the "predicted rank" for each province, calculated from regressing the rank value on the instrumental variables described previously. In this predicted rank ordering, Shanghai is ranked $1^{\text {st }}$ and Sichuan $16^{\text {th }}$, quite consistent with the ordering from rank itself.

${ }^{16}$ Shanghai exported differentiated goods worth $\$ 145$ billion in 2008, 18 times Sichuan’s \$8.2 billion in exports. For referenced prices goods, Shanghai exported \$11 billion in 2008, which is 5 times Sichuan’s \$2.1 billion. For both types of goods, the predicted increase in exports from improving the institutional quality in Sichuan is less than onehalf times the actual difference in exports between the provinces.
} 
this finding is that either a very short amount of time or a very long amount of time might both be indicators of an inefficient court system, so there is no monotonic relationship between the court time variable and institutional quality. ${ }^{17}$

\section{Regression Specification and Initial Results}

To develop the regression specification used in the remainder of the paper, we denote our dependent variable by $\ln Y_{i j r t}$, which is the $\log$ value of exports in industry $i$, contractual mode $j$ (i.e. type of trade and ownership), province $r$, and time $t^{18}$ Indicator variables for contractual mode are denoted by the $(9 \times 1)$ vector $X_{i j t}$, where there are three types of trade (ordinary, pure assembly, and import-and-assembly) interacted with three types of ownership (domestic, joint venture, and foreign). We treat ordinary trade by domestic firms as the omitted category, so without any further interactions there are only 8 types of contractual mode.

We interact $X_{i j r t}$ with each institutional quality variable, denoted $Q_{r}$, which differ across provinces, and also with the Nunn narrow and broad measures of contractual intensity, $z_{i}^{n}$, $n=1,2$, which differ across industries, obtaining the regression:

$$
\ln Y_{i j r t}=\beta_{1}^{\prime} X_{i j r t}+\beta_{2}^{\prime} X_{i j r t} Q_{r}+\beta_{3}^{\prime} X_{i j r t} Q_{r} z_{i}^{n}+\gamma^{\prime} \omega_{i} V_{r t}+\delta_{i}+\delta_{r t}+\varepsilon_{i j r t},
$$

where $\beta_{n}, n=1,2,3$, are $(8 \times 1)$ or $(9 \times 1)$ vectors of coefficients on the contractual mode indicator variables, interacted with institutional quality and also with contractual intensity. ${ }^{19}$ Following

\footnotetext{
${ }^{17}$ We thank Nathan Nunn for this suggestion.

${ }^{18}$ More than one-half of the possible observations for exports $Y_{i j r t}$ are zero and were omitted from the regression. This means that we are examining the impact of institutional quality on the intensive margin of trade and not the extensive margin. The extensive margin of exports across types of trade and ownership will be influenced by factors such as the availability of EPZs in a province, for example. We view the formation of EPZs as a very interesting research topic that we are exploring, but that is beyond the scope of this paper.

${ }^{19}$ The vector $\beta_{1}$ is $(8 \times 1)$ because ordinary trade by domestic firms is the omitted category. When contractual mode is interacted with only institutions, then it is also necessary to omit one category, because the contractual modes sum to unity and the remaining institutional variable is perfectly correlated with the provincial indicators. So we again
} 
Romalis (2004), as well as Nunn (2007), this regression includes the factor endowment variables $V_{r t}=\left(L_{t}^{r} K_{t}^{r}\right)$, interacted with the industry-specific factor intensity $\omega_{i}=\left(\ell_{i}, k_{i}\right)$. We also add indicator variables for industry $\delta_{\mathrm{i}}$, and for province-year $\delta_{r \text { t }}$.

It is evident from our discussion in section 2 that processing trade from the EPZ has greatly expanded since 2001. We would like to know whether these exports have grown especially in provinces with stronger court systems. To assess this, we define a new variable $N_{r t}$ as the cumulative number of EPZ that were opened in province $r$ up to year $t$. Then we can add that variable as a further interaction to obtain:

$$
\begin{aligned}
& \ln Y_{i j r t}=\beta_{1}^{\prime} X_{i j r t}+\beta_{2}^{\prime} X_{i j r t} Q_{r}+\beta_{3}^{\prime} X_{i j r t} Q_{r} z_{i}^{n}+\gamma^{\prime} \omega_{i} V_{r t} \\
& +\beta_{4}^{\prime} X_{i j r t} N_{r t}+\beta_{5}^{\prime} X_{i j r t} Q_{r} N_{r t}+\beta_{6}^{\prime} X_{i j r t} Q_{r} z_{i}^{n} N_{r t}+\delta_{i}+\delta_{r t}+\varepsilon_{i j r t} .
\end{aligned}
$$

We refer to (4) as the EPZ specification. It will allow us to study the role of EPZs as a potential substitute or complement to the institutional quality of court in determining exports from China since 2001, when the EPZs began.

\section{Initial Specification}

We begin with a simple specification in Table 4 that includes the contractual mode indicators $X_{i j r t}$ and their interactions with institutional quality, i.e. $\beta_{1}^{\prime} X_{i j r t}$ and $\beta_{2}^{\prime} X_{i j r t} Q_{r}$ in (4).

We do not report $\beta_{1}$, which are the coefficients of indicator variables for contractual mode and of little interest in themselves. We report the coefficients $\beta_{2}$, which indicate the impact of institutional quality on exports by each contractual mode. The first three rows of estimates in Table 4 refer to pure-assembly processing trade, distinguished by the three ownership types; the 
next three rows refer to import-and-assembly; and the next two rows refer to ordinary trade. We find that relative to ordinary trade by domestic firms (the omitted category), the interactions of our institutional variables, court rank and court cost (instrumented for colonial rule) have a significant effect in raising exports for all contractual modes except for pure assembly combined with joint ventures. A number of the results for court time are not significant, but as discussed in section 2, court time is a weak instrument.

For each mode of trade, we have highlighted the ownership type that gives the largest coefficients. Thus, for pure assembly we find that domestic firms have the largest coefficient an improvement in institutions increases exports by domestic firms the most - while for importand-assembly and ordinary trade, institutions have the greatest impact on exports by foreign firms. These results continue to hold when controlling for provincial factor endowments, in regressions (4)-(6).

The differing impact of institutional quality on exports by domestic and foreign firms is puzzling at first glance, but we offer an explanation drawing on Feenstra and Hanson (2005). They argue that the case of pure assembly (meaning a foreign firm located abroad chooses the inputs sent to China) combined with domestic ownership of firms, or import-and-assembly (meaning the local Chinese manager has control over the inputs) combined with foreign ownership of the firm in China, are both examples of separated ownership and control. In a property-rights model, such separation of ownership and control maintains the incentives for both Chinese and foreign parties to work hard, but the potential cost of noncompliance is higher than if a single owner was fully in control. Having a strong court system can offset this cost of breaching the contract, so by this argument it is not surprising that institutional quality has the greatest marginal impact on exports in these cases of divided ownership and control. 


\section{The Nunn index of contractual intensity}

The findings in Table 4 do not establish causality, and an alternative possibility is that a third factor - namely, geography - can account for the results shown. Specifically, Feenstra and Hanson (2005) find that cases of divided ownership and control are more common in coastal areas, and from Table 2, this is also where institutional quality is stronger. The proximity of Hong Kong, Taiwan, Japan and South Korea to the coastal areas of China, or some other factor, might influence the choice of divided ownership and control while being correlated with institutional quality by virtue of geography. For this reason, we view the results in Table 4 as suggestive but hardly conclusive on the importance of institutions. At the bottom of the table we report the F-tests for weak instruments from the first-stage regression. As we found in Table 3, these F-tests are comfortably greater than 10 except for the court time specification, indicating that the estimates based on court time should be interpreted with caution.

To attempt to establish a causal link between institutions and trade, we add both the narrow and broad contract intensity measures, $z_{i}^{1}$ and $z_{i}^{2}$ of Nunn (2007). We run regressions that

include $\beta_{1}^{\prime} X_{i j r t}$ and $\beta_{2}^{\prime} X_{i j r t} Q_{r}$ as in Table 4, and now also include the interactions, $\beta_{3}^{\prime} X_{i j r t} Q_{r} z_{i}^{n}$, while only reporting the latter coefficients.

In Table 5, the first three rows of estimates again refer to pure assembly, distinguishing the three ownership types; the next three rows refer to import-and-assembly; and the next three rows refer to ordinary trade, all interacted with institutional quality and the Nunn variables. We highlight in bold the ownership type for each mode of trade that gives the high coefficients. Now we see that cases involving foreign ownership benefit the most from higher-quality courts, followed by joint ventures, and followed by domestic firms. The relative importance of institutional quality to foreign-owned firms is consistent across the three measures of quality (rank, time and cost), and across the Nunn narrow and broad measures. By interacting with these 
measures of contractual intensity we are controlling for the impact of geography that influenced the results in Table 4 since identification of the coefficients via the triple-interactions in Table 5 relies on variation in contractual intensity across industries within a province. Thus, we view these results in Table 5 as more credible, indicating the positive impact of institutions on trade by all types of firms, and especially so for foreign firms.

As an example, again consider Sichuan and Shanghai provinces, and specifically foreign assembly firms in the highly differentiated sector Electrical Machinery and Telecommunication Equipment (HS 85), which has a narrow Nunn index of about 0.9 based on the comparable Chinese industry. Then using the interaction term on rank in Table 5 (0.383), and the difference in ranks between these provinces $(23-4=19)$, we predict that if Sichuan acquired the institutional quality of Shanghai, its exports would increase by $\exp (19 \times 0.9 \times 0.383) \approx 700$ times. $^{20}$ Comparing this prediction to the actual values of trade within this sector, the prediction is nearly twice as high as the 395 times difference in exports between these provinces in Semiconductor Devices and Light Emitting Diodes (HS 8541) in 2008, but much smaller than the 4,230 times difference in exports of Electric Space Heaters (HS 8516). It is important to note, however, that the impact of institutions predicted in this way is quite sensitive to the value of the Nunn contractual intensity measure. If we instead focus on somewhat less differentiated goods, such as Textiles (with a narrow Nunn index of 0.6), then if Sichuan acquired the institutions of Shanghai its exports would increase by 80 times. This prediction is very close to the actual difference in exports between these provinces in Men’s and Boy’s shirts (HS 6205), for example.

\section{Variance Explained by Institutional and other Variables}

\footnotetext{
${ }^{20}$ In order to obtain this value we ignore the coefficient on the interaction term that does not include the Nunn contractual intensity variable, even though institutional quality also appears in this term. In so doing, we are in effect ignoring any impact of geography in the thought experiment described here.
} 
With the results in Table 4 and 5, we calculate how much of the variation in trade is explained by institutional and other variables. This is done by applying the technique described as the Frisch-Waugh-Lovell (FWL) theorem in Davidson and MacKinnon, (1993, pp. 19-24), and used by Nunn (2007, p. 583). This procedure regresses the predicted value for institutional interactions from the first stage regression on the indicator variables and the trade-ownership interactions, and likewise for the trade values themselves (as well as interactions of factor endowment and intensity for Table 5), and then reports the $\mathrm{R}^{2}$ of the regression of the export value residual on other residuals. That will give the amount of trade that cannot be explained by the indicator variables, the trade-ownership interactions, and factor endowments as in Table 5. This residual is deemed as being "explained" by the institutional variables.

In the first row of Table 6 , we find that $0.68 \%$ (i.e. less than one percent) of the variance in export value is explained by court rank, in the specification reported in column (1) of Table 4 . Adding the two endowment variables explains a further $0.28 \%$, or $0.96 \%$ in total. Then adding the narrow measure of the Nunn contractual intensity adds 3.28 percentage points, so that $4.24 \%$ is explained in total. If instead we use the broad measure of the Nunn contractual intensity then it adds 2.04 percentage points, so that $3.0 \%$ is explained in total.

Thus, the interaction terms between court rank with contract intensity and contractual mode (i.e. type of trade and ownership), explain $2-3 \%$ of the total variation in export values. Very similar magnitudes are obtained for the other two institutional variables we have used, court time and court cost. In all cases, their interaction with contractual intensity and mode explains $2-3 \%$ of the total variation in exports. While not large, that estimate is very similar to what Nunn (2007) finds for the explanatory power of his index when applied across developing countries. Here, we find similar results within a country - China - using the variation in 
institutional quality across provinces.

\section{Specification with Export Processing Zones}

So far we have made almost no use of the time-series variation in our data (except for controlling with province-year indicator variables). There has been a remarkably growth in Chinese exports over this period, and as discussed in section 2, a simultaneous growth in EPZs. Understanding the extent to which these EPZs contributed to the growth in trade is an important topic not just for China, but for the many developing countries that rely on these zones. Of course, it is not enough to show that exports from the EPZs themselves grew over time, which we take for granted, and which may diminish exports from outside the zone. Rather, we are interested in whether exports in total have grown due to EPZs. Here we just begin to answer this question by exploring whether institutional quality has made the same contribution to increased exports in provinces with growing EPZs as otherwise.

The EPZ specification in (4) includes the variable $N_{r t}$, the cumulative number of export processing zones that were opened in province $r$ since 2001. We interact that term with nearly all other variables in the regression (except the factor endowments), leading to a large number of estimated coefficients. For brevity, we first discuss some of these coefficients in general terms and then report the coefficients of special interest.

The impact of the EPZs interacted with contractual mode (ownership and type of trade), $\beta_{4}^{\prime} X_{i j r t} N_{r t}$ in (4), shows that these zones increase the exports of foreign firms engaged in processing trade, with coefficients around $0.3^{21}$. Perhaps surprisingly, they also increase the exports of foreign firms engaged in ordinary trade, with a coefficient of nearly the same

\footnotetext{
${ }^{21}$ For brevity, we are not reporting the coefficients $\beta_{4}$ in a table. They are available upon request.
} 
magnitude. One explanation for this result is that the EPZs could attract foreign firms that also engage in production and export outside the zone ${ }^{22}$. The EPZs increase the exports of joint ventures by less than one-half as much as for fully-owned foreign firms, and reduce the exports of domestic firms in either processing or ordinary trade. So evidently the foreign firms entering EPZs draw resources away from domestic firms.

Adding institutional quality to the interaction of EPZs and contractual mode, we obtain the term $\beta_{5}^{\prime} X_{i j r t} Q_{r} N_{r t}$ in (4). All the coefficients $\beta_{5}$ are small, such as 0.1 or less. They are positive in the same cases where $\beta_{4}$ is positive, indicating that higher-quality courts add to the impact of EPZ on the exports of foreign and domestic firms. That is, the positive (negative) impact of EPZs on exports by foreign (domestic) firms becomes even larger. However, we view these results as subject to the same criticism we made of the results in Table 4: they can be influenced by geography acting as another factor simultaneously influencing institutions, the location of EPZs, and exports.

To avoid the sensitivity of our results to geography, we add the Nunn contractual intensity variable as a further interaction, by including the term $\beta_{6}^{\prime} X_{i j r t} Q_{r} z_{i}^{n} N_{r t}$ from (4). The coefficients $\beta_{6}$ are reported in Table 7 , together with the coefficient $\beta_{3}$ on the interactions $\beta_{3}^{\prime} X_{i j r t} Q_{r} z_{i}^{n}$ without the EPZ, similar to the coefficients, $\beta_{3}$, reported in Table 5 . Both these sets of interactions between institutions, contractual intensity, contractual mode and possibly the number of EPZ are identified by variation in contractual intensity across industries and not across provinces, so that geography cannot act as a causal factor. For brevity, we only report in Table 7 court rank as an institutional variable, using two Nunn variables (narrow and broad). Qualitatively similar results are obtained using court time and court cost.

\footnotetext{
${ }^{22}$ Examples of firms located in the EPZs include Intel Co. (Chengdu Branch), Sharp Co., Toshiba, etc.
} 
The coefficient $\beta_{3}$ reported in Table 7 , on the interactions between institutional quality and contract intensity without the EPZ, differ in magnitude from what was found in Table 5: the coefficient for foreign firms engaged in pure assembly falls from 0.383 to 0.200 , for example, while the coefficients for foreign firms engaged in import-and-assembly and ordinary trade both rise. More importantly, the coefficients $\beta_{6}$ on the interactions between institution, contract intensity and the EPZ are all negative (or insignificant) for foreign firms and positive (or insignificant) for domestic firms. That is, having higher-quality institutions in provinces with more EPZ actually benefits domestic firms to the detriment of foreign firms, regardless of the type of trade. These coefficients in Table 7 are not that large, and not always significant, but are intriguing nonetheless.

One explanation for these findings in Table 7 is that the EPZ themselves are a type of institution that regulates processing trade and takes the place of having a strong court system. China initiated the EPZ in 2001 in response to its accession into the WTO. The idea was to bring processing trade more fully under the control of central authority, by reducing the smuggling of duty-free processing imports into the domestic economy, offering reduced taxes on this activity, etc. For provinces with a small number of EPZ, then the court system continues to be the dominant institution supporting the exports of foreign firms, and an improvement in institutional quality would still increase these exports. But for provinces with a large number of EPZ, it could be expected that a hypothetical change in court quality would have a more modest impact on exports, because the EPZ essentially substitute for the court system.

To illustrate this argument, we compare Sichuan and Shanghai once again. In 2008, Sichuan had two EPZs and Shanghai had seven, with only one other province having more (Jiangsu had 13). For foreign assembly firms in an industry of "average" contract intensity ( $z_{i}^{1}=$ 
0.75) operating in these provinces, we first raise the institutional quality of Sichuan (court rank = 23) to the level of Shanghai (court rank =4). The coefficients in Table 7 indicate that foreign firms engaged in pure assembly in Sichuan would increase their exports by $\exp (19 \times 0.75 \times 0.2-$ $19 \times 0.75 \times 2 \times 0.026)=8.2$ times, where the negative term in this calculation comes from the negative coefficient $\beta_{6}$ on the interaction between institution, contract-intensity, and EPZ. Due to the small number of EPZ in Sichuan (only two), this negative interaction is small and hence raising Sichuan court-rank has a large predicted effect on the magnitude of trade by foreign firms (about eight times).

Conversely, consider hypothetically lowering institutions in Shanghai to the level of Sichuan. Because Shanghai already has seven EPZs, its exports by foreign firms engaged in pure assembly are predicted to fall by only $\exp (-19 \times 0.75 \times 0.2+19 \times 0.75 \times 7 \times 0.026)=0.75$, or threequarters of their current level. In this case, the rather drastic reduction in institutional quality, by 19 ranks, has only a modest impact on exports because of the high number of EPZ present in Shanghai. In this sense, the EPZ serve as a substitute for court quality, and are an important institutional feature in their own right.

\section{Variance Explained by Institutional Quality and EPZ}

Again applying the Frisch-Waugh-Lovell (FWL) theorem, we can estimate the percent variation in log exports explained by adding the growth in EPZs to the regressions as an additional interaction term. Returning to Table 6, the bottom three rows indicate that overall these variables increased the fit of the model, though not by overwhelming amounts. Furthermore, comparing the first row in the EPZ specification with the second and third in Table 6 , it is clear that adding contract intensity increases the model's fit more than does just adding the number of EPZs. 
Focusing on the case reflected in columns (1) and (3) of Table 7 in which contractual intensity is measured according to Nunn's narrow definition, the inclusion of EPZ growth improved the model's fit by an additional $0.87 \%(=0.0511-0.0424)$, or close to one percent, when institutional quality is represented by court rank, and nearly identical magnitudes when represented by court time or court cost. In the case where contractual intensity is measured using the broad definition, there is a similar pattern. The addition of EPZs increases the explained variation by $0.44 \%(0.0344-0.030)$, or about one-half of one percent, when court rank is used to represent institutional quality, with similar results in the case of the alternative measures. We conclude that an additional $0.5-1 \%$ of the variation in export values is explained by the growth of the EPZs since 2001.

\section{Conclusions}

Several recent papers (Levchenko, 2007, Nunn 2007 and Ranjan and Lee, 2007) provide evidence that institutional quality is important for both the volume of trade and the ability to trade in differentiated goods that rely on contract enforcement. However, the limitations of the country-level data used by these authors (either U.S. imports or world trade data) means that only indirect measures are used to identify those imports or exports that are more institutionally dependent due to their greater need for contract enforcement. In this paper, we depart from this literature by using province level variation in institutional quality within China to identify the effects of better institutions on the nature and pattern of Chinese exports. A major advantage is that the Chinese trade data distinguishes between categories of exports (processing or ordinary) and categories of ownership (foreign or domestic) that differ in the importance of contract enforcement. We refer to these categories as “contractual modes” of exports. 
Since obtaining the custom's designation for duty-free import typically requires proof of an export contract, it is natural to suppose that contract enforcement is more important for processing trade than for the residual category of ordinary trade, for which no special customs declaration is required. It is also reasonable to expect that foreign firms producing in China would be more institutionally dependent than domestic firms. Our consideration of institutional quality within China also has the feature that we are able to calculate the Nunn index of contractual intensity with industry weights that vary appropriately depending on whether the index applies to processing or ordinary trade.

Turning to the empirical results, a preliminary analysis in Table 3 shows that the provincial data exhibits the expected relationship between institutional quality and the volume of exports: better institutional quality tends to increase the exports of both differentiated goods and reference priced goods (relative to homogeneous goods) with the magnitude of the effect being much smaller for reference priced goods.

Our main analysis incorporates the various contractual modes of exports. In addition to ordinary trade, we distinguish two types of processing trade: pure-assembly in which a foreign firm controls (and owns) the materials supplied to the factory in China and import and assembly in which the factory in China controls the purchase of materials from abroad. We also distinguish three types of ownership: domestic, joint venture and foreign.

Table 4 is estimated using a simple interaction of the various contractual modes of exports and our measures of institutional quality. We find that relative to ordinary trade by domestic firms (the omitted category), the interactions of our institutional variables, court rank and court cost (instrumented for colonial rule) have a significant effect in raising exports for almost all contractual modes. For import and assembly and ordinary trade, institutions have the 
greatest impact on exports by foreign firms, but for pure assembly we find, somewhat surprisingly, that institutions affect domestic firms the most. We provide an explanation based on the possibility that institutions are more important when there is separation of ownership and control, but our primary possibility is that the results may be affected due to the failure to fully account for a third factor, namely the importance of location at the coast.

We address this problem by adding a three way interaction in which the Nunn measure of contract intensity is combined with institutional quality and contractual mode. As shown in Table 5, this three-way interaction term is positive and significant for all our measures of institutional quality and all contractual modes. Moreover, for every type of trade, including pure assembly, exports by foreign firms are most affected by the quality of institutions. Joint ventures are next most affected, followed by domestic firms.

A very interesting aspect of the Chinese data is the growth of EPZs since China joined the WTO in 2001. We examine whether these zones act as a substitute or a complement for institutional quality; that is, whether strong courts reinforce the impact of EPZs or whether these zones substitute for court authority. For this purpose, we add a four-way interaction term in which the accumulated number of EPZs in each province since 2001 is interacted with the quality of institutions, the Nunn measure of contract intensity and contractual mode. Table 7 reports the coefficients for the three-way and four-way interaction terms for court rank. We find that an increase in the number of EPZs offsets the tendency for an improvement in court-rank to raise the exports of foreign firms. This finding provides support for the idea that the regulation and control of processing trade within the EPZs represents a form of institutional quality that is a substitute for a strong court system, at least for foreign firms. 


\section{References}

Acemoglu, Daron, and Melissa Dell, 2009, “Beyond Neoclassical Growth: Technology, Human Capital, Institutions and Within Country Difference”, MIT.

Acemoglu, Daron, and Melissa Dell, Forthcoming, "Productivity Differences Between and Within Countries”, American Economic Journal: Macroeconomics.

Acemoglu, Daron, Simon Johnson, and James Robinson, 2001, “The Colonial Origins of Comparative Development: An Empirical Investigation”. American Economic Review 91.

Acemoglu, Daron, Simon Johnson, and James Robinson, 2002, “Reversal of Fortune: Geography and Institutions in the Making of the Modern World Income Distribution”. Quarterly Journal of Economics 117.

Ahn, JaeBin, Amit Khandelwal, and Shang-Jin Wei, 2010, “The Role of Intermediaries in Facilitating Trade,” Columbia University.

Bai, Chong-En, Chang-Tai Hsieh, and Yingyi Qian, 2006, “The Return to Capital in China”, Brookings Papers on Economic Activity, II.

Davidson, Russel, and James G. MacKinnon, 1993, Estimation and Inference in Econometrics, New York: Oxford University Press.

Djankov, Simeon , Rafael La Porta, Florencio Lopez-de-Silanes, and Andrei Shleifer, 2002 “Courts: The Lex Mundi Project,” NBER Working paper 8890.

Du, Julan, Yi Lu, and Zhigang Tao, 2010, “Contract Institutions and Vertical Integration: Evidence from China’s Manufacturing Firms”. University of Hong Kong.

Feenstra, Robert C. and Gordon H. Hanson, 2005, Ownership and Control in Outsourcing to China: Estimating the Property-Rights Theory of the Firm,” Quarterly Journal of Economics, 120(2), May 2005, 729-762.

Feenstra, Robert C. and Barbara Spencer, 2005, “Contractual versus Generic Outsourcing: The Role of Proximity,” NBER working paper 11885.

La Porta, Raael, Florencio Lopez-de-Silanes, Andrei Shleifer, and Robert Vishny. 1997. "Legal Determinants of External Finance", Journal of Finance 52.

La Porta, Raael, Florencio Lopez-de-Silanes, Andrei Shleifer and, Robert Vishny. 1998. "Law and Finance", Journal of Political Economy 106.

Levchenko, Andrei A., 2007, “Institutional Quality and International Trade,” Review of Economic Studies, 74, 791-819.

Lu, Yi, Ivan Png, and Zhigang Tao, 2008, “Do Institutions Not Matter in China? Evidence from Enterprise-Level Productivity Growth”, University of Hong Kong Working paper,

Manova, Kalina and Zhiwei Zhang, 2009, “Export Prices and Heterogeneous Firm Models” NBER Working Paper 15342. 
Naughton, Barry, 1996, “China’s Emergence and Prospects as a Trading Nation,” Brookings Papers on Economic Activity, II, 273-343.

Nunn, Nathan, 2007, "Relationship-Specificity, Incomplete Contracts, and The Pattern of Trade,” Quarterly Journal of Economics, May, 569-600.

Ranjan, Priya and Jae Young Lee, 2007, “Contract Enforcement and International Trade,” Economics and Politics, 19(2), July, 191-218.

Rauch, James E., 1999, “Networks versus Markets in International Trade,” Journal of International Economics, 48, 7-37.

Romalis, John, 2004, "Factor Proportions and the Structure of Commodity Trade”, American Economic Review, 94: 67-97.

Stock, James H., Jonathan H. Wright and Motohiro Yogo, 2002, “A Survey of Weak Instruments and Weak Identification in Generalized Method of Moments," Journal of Business \& Economic Statistics, October, 20(4), 518-529.

World Bank, 1994, China: Foreign Trade Reform, Washington, DC.: The World Bank.

World Bank, 2008, Doing Business in China 2008. Available at: www.doingbusiness.org/china. 


\section{Table 1: Export Processing, Foreign Ownership and Trade in China}

\begin{tabular}{|c|c|c|c|c|c|c|}
\hline \multirow{3}{*}{ Year } & \multirow{3}{*}{$\begin{array}{l}\text { Processing } \\
\text { exports/ } \\
\text { Total } \\
\text { exports } \\
(1) \\
\end{array}$} & \multirow{3}{*}{$\begin{array}{c}\text { Exports by } \\
\text { foreign firms/ } \\
\text { Total } \\
\text { exports } \\
(2)\end{array}$} & \multicolumn{2}{|c|}{$\begin{array}{l}\text { Share in total processing } \\
\text { exports of: }\end{array}$} & \multirow{2}{*}{$\begin{array}{c}\text { Number of } \\
\text { export } \\
\text { processing } \\
\text { zones (EPZ) }\end{array}$} & \multirow{2}{*}{$\begin{array}{l}\text { Exports } \\
\text { from EPZ/ } \\
\text { Total } \\
\text { exports } \\
\end{array}$} \\
\hline & & & $\begin{array}{c}\text { Exports by } \\
\text { Foreign Firms }\end{array}$ & $\begin{array}{l}\text { Import-and- } \\
\text { assembly }\end{array}$ & & \\
\hline & & & (3) & (4) & (5) & (6) \\
\hline 1997 & 0.545 & 0.361 & 0.561 & 0.704 & 0 & 0.000 \\
\hline 1998 & 0.568 & 0.393 & 0.587 & 0.705 & 0 & 0.000 \\
\hline 1999 & 0.568 & 0.413 & 0.609 & 0.677 & 0 & 0.000 \\
\hline 2000 & 0.552 & 0.439 & 0.646 & 0.701 & 0 & 0.000 \\
\hline 2001 & 0.554 & 0.462 & 0.669 & 0.714 & 8 & 0.001 \\
\hline 2002 & 0.553 & 0.486 & 0.699 & 0.736 & 15 & 0.007 \\
\hline 2003 & 0.552 & 0.518 & 0.747 & 0.775 & 19 & 0.023 \\
\hline 2004 & 0.553 & 0.546 & 0.780 & 0.791 & 28 & 0.035 \\
\hline 2005 & 0.547 & 0.562 & 0.806 & 0.798 & 32 & 0.046 \\
\hline 2006 & 0.527 & 0.564 & 0.820 & 0.815 & 35 & 0.056 \\
\hline 2007 & 0.507 & 0.556 & 0.825 & 0.812 & 42 & 0.062 \\
\hline 2008 & 0.473 & 0.541 & 0.831 & 0.836 & 50 & 0.071 \\
\hline
\end{tabular}

Notes: Columns (1) and (2) show processing exports and exports by foreign firms, respectively, as a share of total China exports; columns (3) and (4) show as a share of total China processing exports, processing exports by foreign firms, and processing exports under the import-and-assembly regime; column (5) shows the number of export processing zones (EPZ) in China; and column (6) shows the share of total exports accounted for by the EPZ. Source: The Customs General Administration of the People’s Republic of China. 
Table 2: Summary Statistics for Institutional Variables

\begin{tabular}{c|c|ccccc}
\hline Area & Variable & Obs. & Mean & Std. Dev. & Min & Max \\
\hline \hline Southeast & rank & 6 & 25.5 & 4.8 & 19 & 30 \\
$\begin{array}{c}\text { Coastal } \\
\text { Provinces }\end{array}$ & time & 6 & 356.5 & 100.7 & 258 & 488 \\
\hline cost & 6 & 38.1 & 2.3 & 35.5 & 41 \\
\hline $\begin{array}{c}\text { Interior and } \\
\text { Northern } \\
\text { Provinces }\end{array}$ & rank & 24 & 13.2 & 7.9 & 1 & 26 \\
\hline
\end{tabular}

Notes: We report three measures of court efficiency as indicators of institutional quality: rank, time and cost (see main text for description). All together there are 30 provinces. Provinces of the Southeast coastal area (top panel) include Fujian, Guangdong, Hainan, Jiangsu, Shanghai, and Zhejiang; with the rest being interior and northern provinces. Here we report the summary statistics for rescaled data, so a higher number means higher efficiency (to be concrete, we define rank as 31-original rank, time as 600-original time, and cost as 50-original cost). 
Table 3: Regression using Rauch Classification

\begin{tabular}{lccccccc}
\hline & \multicolumn{3}{c}{ OLS } & \multicolumn{3}{c}{ IV } \\
\cline { 2 - 7 } & \multicolumn{3}{c}{ Institutional Variable: } & \multicolumn{3}{c}{ Institutional Variable: } \\
& $\mathbf{( 1 )}$ & $\mathbf{( 2 )}$ & $\mathbf{( 3 )}$ & $\mathbf{( 4 )}$ & $\mathbf{( 5 )}$ & $\mathbf{( 6 )}$ \\
Independent variables: & rank & time & cost & rank & time & cost \\
\hline Institutions*Differentiated Goods & $0.112^{* * *}$ & $0.009^{* * *}$ & $0.080^{* *}$ & $0.105^{* * *}$ & $0.016^{* * *}$ & $0.033^{* * *}$ \\
& $(0.02)$ & $(0.00)$ & $(0.03)$ & $(0.01)$ & $(0.00)$ & $(0.01)$ \\
& $0.046^{* * *}$ & $0.004^{* * *}$ & $0.033^{*}$ & $0.031^{* * *}$ & $0.009^{* * *}$ & 0.000 \\
Institutions*Reference-Priced Goods & $(0.01)$ & $(0.00)$ & $(0.02)$ & $(0.01)$ & $(0.00)$ & $(0.01)$ \\
Differentiated Goods & 0.298 & -0.547 & -0.214 & $0.399^{* *}$ & $-2.570^{* * *}$ & $1.124^{* * *}$ \\
& $(0.39)$ & $(0.67)$ & $(1.02)$ & $(0.19)$ & $(0.60)$ & $(0.35)$ \\
Reference-Priced Goods & $0.341^{*}$ & -0.012 & 0.126 & $0.570^{* * *}$ & $-1.431^{* * *}$ & $1.055^{* * *}$ \\
& $(0.19)$ & $(0.38)$ & $(0.47)$ & $(0.18)$ & $(0.47)$ & $(0.30)$ \\
Observations & 990 & 990 & 990 & 990 & 990 & 990 \\
Province-year fixed effect & yes & yes & yes & yes & yes & yes \\
R-squared & 0.913 & 0.896 & 0.888 & 0.912 & 0.873 & 0.877 \\
\hline First Stage F-Test & & & & 109.0 & 8.4 & 79.4 \\
\hline
\end{tabular}

Notes: Dependent variable is log(export value). The panel covers 30 provinces over 1997-2007. Differentiated goods as well as reference-priced goods are classified according to Rauch (1999). There are three proxies for institutional quality: the rank of court efficiency, the average time used to solve a dispute, and the official costs associated with going through court procedure. The first three columns are OLS regression, while the last three columns are using instruments which include the interaction terms of product categories with the occupancy of foreign powers (Britain, France, Russia, and multiple powers) in each province, as well as with the provincial population in 1953. Robust standard errors in parentheses.

* significant at $10 \%$; ** significant at $5 \%$; ** significant at $1 \%$. 
Table 4: Regression without Nunn Contractual Intensity

\begin{tabular}{|c|c|c|c|c|c|c|}
\hline \multirow[b]{2}{*}{ Independent Variables: } & \multicolumn{3}{|c|}{ Institutional Variable: } & \multicolumn{3}{|c|}{ Institutional Variable: } \\
\hline & $\begin{array}{l}\text { (1) } \\
\text { rank }\end{array}$ & $\begin{array}{l}(2) \\
\text { time }\end{array}$ & $\begin{array}{l}\text { (3) } \\
\text { cost }\end{array}$ & $\begin{array}{l}\text { (4) } \\
\text { rank }\end{array}$ & $\begin{array}{c}(5) \\
\text { time }\end{array}$ & $\begin{array}{l}(6) \\
\text { cost }\end{array}$ \\
\hline $\begin{array}{l}\text { Institutions*Pure } \\
\text { Assembly*Domestic }\end{array}$ & $\begin{array}{c}0.120 * * * \\
(0.02)\end{array}$ & $\begin{array}{c}\mathbf{0 . 0 0 7 * *} \\
(0.00)\end{array}$ & $\begin{array}{c}0.092 * * * \\
(0.02)\end{array}$ & $\begin{array}{c}\mathbf{0 . 1 3 3} * * * \\
(0.03)\end{array}$ & $\begin{array}{c}\mathbf{0 . 0 0 6 * *} \\
(0.00)\end{array}$ & $\begin{array}{c}0.105^{* * *} \\
(0.02)\end{array}$ \\
\hline $\begin{array}{l}\text { Institutions*Pure } \\
\text { Assembly*Joint Venture }\end{array}$ & $\begin{array}{l}0.032 \\
(0.03)\end{array}$ & $\begin{array}{l}0.001 \\
(0.00)\end{array}$ & $\begin{array}{l}0.011 \\
(0.02)\end{array}$ & $\begin{array}{l}0.046 \\
(0.03)\end{array}$ & $\begin{array}{l}0.000 \\
(0.00)\end{array}$ & $\begin{array}{l}0.025 \\
(0.02)\end{array}$ \\
\hline $\begin{array}{l}\text { Institutions*Pure } \\
\text { Assembly*Foreign }\end{array}$ & $\begin{array}{c}0.091^{* * *} \\
(0.03)\end{array}$ & $\begin{array}{l}0.003 \\
(0.00)\end{array}$ & $\begin{array}{c}0.052^{* *} \\
(0.02)\end{array}$ & $\begin{array}{c}0.104 * * * \\
(0.03)\end{array}$ & $\begin{array}{l}0.002 \\
(0.00)\end{array}$ & $\begin{array}{c}0.065^{* * *} \\
(0.02)\end{array}$ \\
\hline $\begin{array}{l}\text { Institutions*Import and } \\
\text { Assembly*Domestic }\end{array}$ & $\begin{array}{c}0.050 * * * \\
(0.02)\end{array}$ & $\begin{array}{l}0.002 \\
(0.00)\end{array}$ & $\begin{array}{l}0.029^{*} \\
(0.02)\end{array}$ & $\begin{array}{c}0.064^{* * *} \\
(0.02)\end{array}$ & $\begin{array}{l}0.001 \\
(0.00)\end{array}$ & $\begin{array}{c}0.043^{* * *} \\
(0.02)\end{array}$ \\
\hline $\begin{array}{l}\text { Institutions*Import and } \\
\text { Assembly*Joint Venture }\end{array}$ & $\begin{array}{c}0.102^{* * *} \\
(0.03)\end{array}$ & $\begin{array}{l}0.003 \\
(0.00)\end{array}$ & $\begin{array}{c}0.057^{* * *} \\
(0.02)\end{array}$ & $\begin{array}{c}0.115^{* * *} \\
(0.03)\end{array}$ & $\begin{array}{l}0.002 \\
(0.00)\end{array}$ & $\begin{array}{c}0.070^{* * *} \\
(0.02)\end{array}$ \\
\hline $\begin{array}{l}\text { Institutions*Import and } \\
\text { Assembly*Foreign }\end{array}$ & $\begin{array}{c}\mathbf{0 . 1 6 7 * * *} \\
(0.03)\end{array}$ & $\begin{array}{c}\mathbf{0 . 0 0 7 * *} \\
(0.00)\end{array}$ & $\begin{array}{c}0.094^{* * *} \\
(0.02)\end{array}$ & $\begin{array}{c}\mathbf{0 . 1 8 2 * * *} \\
(0.03)\end{array}$ & $\begin{array}{c}0.006^{* *} \\
(0.00)\end{array}$ & $\begin{array}{c}0.108^{* * *} \\
(0.02)\end{array}$ \\
\hline $\begin{array}{l}\text { Institutions*Ordinary } \\
\text { *Joint Venture }\end{array}$ & $\begin{array}{c}0.074^{* * *} \\
(0.02)\end{array}$ & $\begin{array}{c}0.006^{* *} \\
(0.00)\end{array}$ & $\begin{array}{l}0.002 \\
(0.02)\end{array}$ & $\begin{array}{c}0.076 * * * \\
(0.02)\end{array}$ & $\begin{array}{c}0.006^{* *} \\
(0.00)\end{array}$ & $\begin{array}{l}0.005 \\
(0.02)\end{array}$ \\
\hline $\begin{array}{l}\text { Institutions*Ordinary } \\
\text { *Foreign }\end{array}$ & $\begin{array}{c}\mathbf{0 . 1 1 9 * * *} \\
(0.02)\end{array}$ & $\begin{array}{c}0.007^{* *} \\
(0.00)\end{array}$ & $\begin{array}{c}\mathbf{0 . 0 4 4 ^ { * * }} \\
(0.02)\end{array}$ & $\begin{array}{c}0.121 * * * \\
(0.02)\end{array}$ & $\begin{array}{c}0.007^{* *} \\
(0.00)\end{array}$ & $\begin{array}{c}0.047^{* * *} \\
(0.02)\end{array}$ \\
\hline Skill*Labor Intensity & & & & $\begin{array}{c}0.621^{* * *} \\
(0.20)\end{array}$ & $\begin{array}{c}0.575^{* * *} \\
(0.21)\end{array}$ & $\begin{array}{c}0.642^{* * *} \\
(0.20)\end{array}$ \\
\hline Capital*Capital Intensity & & & & $\begin{array}{l}2.641^{*} \\
(1.59)\end{array}$ & $\begin{array}{l}-0.038 \\
(1.30)\end{array}$ & $\begin{array}{l}2.750^{*} \\
(1.46)\end{array}$ \\
\hline Province-year fixed effect & yes & yes & yes & Yes & yes & yes \\
\hline $\begin{array}{l}\text { Trade type and Ownership } \\
\text { Interactions }\end{array}$ & yes & yes & yes & Yes & yes & yes \\
\hline Observations & 38,638 & 38,638 & 38,638 & 38,638 & 38,638 & 38,638 \\
\hline First Stage F-Test & $F>24$ & $5<F<8$ & $F>24$ & $F>19$ & $5<F<8$ & $F>23$ \\
\hline
\end{tabular}

Notes: Dependent variable: $\log ($ export value). The panel covers 30 provinces over 1997-2007. We categorize exports by industry, and by custom regime (pure-assembly, import-and-assembly, and ordinary exports) and ownership of the exporter (domestic, equity joint venture, and wholly foreign owned). There are three proxies for institutional quality: the rank of court efficiency, the average time used to solve a dispute, and the official costs associated with going through court procedure. All estimation is performed with instruments, which include the interaction terms of export categories with the occupancy of foreign powers (Britain, France, Russia, and multiple powers) in each province, as well as with the provincial population in 1953. All regressions have province-year fixed effect, and also trade-type-ownership interactions. Robust clustered standard errors in parentheses.

* significant at $10 \%$; ** significant at $5 \%$; ** significant at $1 \%$. 
Table 5: Regression with Nunn Contractual Intensity

\begin{tabular}{|c|c|c|c|c|c|c|}
\hline \multirow[b]{2}{*}{ Independent Variables: } & \multicolumn{3}{|c|}{ Nunn Narrow measure $z_{i}^{1}$} & \multicolumn{3}{|c|}{ Nunn Broad measure $z_{i}^{2}$} \\
\hline & $\begin{array}{c}\text { (1) } \\
\text { rank }\end{array}$ & $\begin{array}{c}\text { (2) } \\
\text { time }\end{array}$ & $\begin{array}{l}\text { (3) } \\
\text { cost }\end{array}$ & $\begin{array}{c}\text { (4) } \\
\text { rank }\end{array}$ & $\begin{array}{c}(5) \\
\text { time }\end{array}$ & $\begin{array}{l}(6) \\
\text { cost }\end{array}$ \\
\hline Institutions* $z_{i}^{n} *$ Pure & $0.209 * * *$ & $0.013^{* * *}$ & $0.130 * * *$ & $0.194^{* * *}$ & $0.012 * * *$ & $0.118^{* * *}$ \\
\hline Assembly*Domestic & $(0.04)$ & $(0.00)$ & $(0.02)$ & $(0.07)$ & $(0.00)$ & $(0.04)$ \\
\hline Institutions* $z_{i}^{n} *$ Pure & $0.287^{* * *}$ & $0.019 * * *$ & $0.184 * * *$ & $0.416 * * *$ & $0.028 * * *$ & $0.262 * * *$ \\
\hline Assembly*Joint Venture & $(0.03)$ & $(0.00)$ & $(0.02)$ & $(0.07)$ & $(0.01)$ & $(0.04)$ \\
\hline Institutions* $z_{i}^{n} *$ Pure & $0.383 * * *$ & $0.025 * * *$ & $0.237 * * *$ & $0.564 * * *$ & $0.035 * * *$ & $0.343 * * *$ \\
\hline Assembly*Foreign & $(0.04)$ & $(0.00)$ & $(0.02)$ & $(0.07)$ & $(0.01)$ & $(0.04)$ \\
\hline Institutions* $z_{i}^{n} *$ Import \& & $0.220 * * *$ & $0.014^{* * *}$ & $0.131^{* * *}$ & $0.246 * * *$ & $0.015^{* * *}$ & $0.142^{* * *}$ \\
\hline Assembly*Domestic & $(0.03)$ & $(0.00)$ & $(0.02)$ & $(0.06)$ & $(0.00)$ & $(0.04)$ \\
\hline Institutions* $z_{j}^{n}{ }^{*}$ Import \& & $0.351^{* * *}$ & $0.022 * * *$ & $0.218^{* * *}$ & $0.492 * * *$ & $0.031 * * *$ & $0.297^{* * *}$ \\
\hline Assembly*Joint Venture & $(0.03)$ & $(0.00)$ & $(0.02)$ & $(0.06)$ & $(0.00)$ & $(0.04)$ \\
\hline Institutions* $z_{i}^{n} *$ Import \& & $0.362^{* * *}$ & $0.023 * * *$ & $0.226 * * *$ & $0.553^{* * *}$ & $0.034^{* * *}$ & $0.334^{* * *}$ \\
\hline Assembly*Foreign & $(0.03)$ & $(0.00)$ & $(0.02)$ & $(0.06)$ & $(0.00)$ & $(0.04)$ \\
\hline Institutions* $Z_{i}^{n} *$ & $0.161^{* * *}$ & $0.010 * * *$ & $0.093 * * *$ & $0.215^{* * *}$ & $0.013^{* * *}$ & $0.122^{* * *}$ \\
\hline *Ordinary*Domestic & $(0.04)$ & $(0.00)$ & $(0.02)$ & $(0.07)$ & $(0.01)$ & $(0.05)$ \\
\hline Institutions* $z_{i}^{n} *$ Ordinary & $0.211^{* * *}$ & $0.013^{* * *}$ & $0.126^{* * *}$ & $0.211^{* * *}$ & $0.013^{* * *}$ & $0.119 * * *$ \\
\hline *Joint Venture & $(0.04)$ & $(0.00)$ & $(0.03)$ & $(0.07)$ & $(0.00)$ & $(0.05)$ \\
\hline Institutions $* z_{i}^{n} *$ Ordinary & $0.245^{* * *}$ & $0.015^{* * *}$ & $0.149 * * *$ & $0.230 * * *$ & $0.014 * * *$ & $0.132 * * *$ \\
\hline *Foreign & $(0.04)$ & $(0.00)$ & $(0.03)$ & $(0.07)$ & $(0.00)$ & $(0.05)$ \\
\hline \multirow{2}{*}{ Skill*Labor Intensity } & $0.505^{* * *}$ & $0.451^{* * *}$ & $0.513^{* * *}$ & $0.426 * *$ & $0.387^{* *}$ & $0.440 * * *$ \\
\hline & $(0.16)$ & $(0.17)$ & $(0.16)$ & $(0.17)$ & $(0.18)$ & $(0.17)$ \\
\hline \multirow{2}{*}{ Capital*Capital Intensity } & -0.466 & -1.238 & 0.613 & 1.227 & -0.74 & 1.69 \\
\hline & $(1.52)$ & $(1.26)$ & $(1.37)$ & $(1.55)$ & $(1.28)$ & $(1.43)$ \\
\hline Province-year fixed effect & yes & yes & yes & Yes & yes & Yes \\
\hline \multicolumn{7}{|l|}{ Trade type and Ownership } \\
\hline Interactions & yes & yes & yes & Yes & yes & Yes \\
\hline \multicolumn{7}{|l|}{ Institutions, Trade type \& } \\
\hline Ownership Interactions & yes & yes & yes & Yes & yes & Yes \\
\hline Observations & 38,638 & 38,638 & 38,638 & 38,638 & 38,638 & 38,638 \\
\hline First Stage F-Test & $F>194$ & $\mathrm{~F}>110$ & $F>44$ & $F>46$ & $F>21$ & $\mathrm{~F}>18$ \\
\hline
\end{tabular}

Notes: See the notes to Table 4. The interactions terms reported in Table 4 are also included in these regressions but not reported for brevity. The variable $z_{i}^{n}$ measures the differentiation of their intermediate inputs using the Rauch (1999) classification: $z_{i}^{1}$ is the share of intermediate inputs that are differentiated, while $z_{i}^{2}$ is the share of intermediate inputs that are differentiated or reference-priced. 


\section{Table 6: Proportion of Variance Explained by Institutional and Other Variables}

\begin{tabular}{lccc}
\hline & \multicolumn{3}{c}{ Institutional variable: } \\
Regression: & rank & time & cost \\
\hline Initial Specification: & & & \\
Without endowments or contract intensity & 0.0068 & 0.0018 & 0.0059 \\
With endowments, without contract intensity & 0.0096 & 0.0044 & 0.0091 \\
With narrow contract intensity $Z_{i}^{1}$ & 0.0424 & 0.0349 & 0.0398 \\
With broad contract intensity $Z_{i}^{2}$ & 0.0300 & 0.0227 & 0.0282 \\
EPZ Specification: & & & \\
Without contract intensity, with $N_{r t}$ & 0.0193 & 0.0144 & 0.0185 \\
With narrow contract intensity $Z_{i}^{1}$ and $N_{r t}$ & 0.0511 & 0.0435 & 0.0490 \\
With broad contract intensity $z_{i}^{2}$ and $N_{r t}$ & 0.0344 & 0.0297 & 0.0338 \\
& & & \\
\hline
\end{tabular}

Notes: This table reports the variance of the value of trade accounted for by the regression variables without fixed effects. These variances are measured by the Frisch-Waugh-Lovell (FWL) theorem, as follows: First, we regress the predicted value for institutional interactions from the first stage regression on the indicator variables and the trade-ownership interactions, and likewise for the trade values themselves (as well as interactions of factor endowment and intensity for Table 5, and interactions of EPZs and indicators for Table 7), and then report the $\mathrm{R}^{2}$ of the regression of the export value residual on other residuals. 


\section{Table 7: Regression with Export Processing Zones and with Nunn Contractual Intensity}

\begin{tabular}{|c|c|c|c|c|c|}
\hline $\begin{array}{l}\text { Nunn Variable Type: } \\
\text { Independent Variables: }\end{array}$ & $\begin{array}{c}\text { Narrow } \\
\text { (1) } \\
\text { rank }\end{array}$ & $\begin{array}{l}\text { Broad } \\
(2) \\
\text { rank }\end{array}$ & $\begin{array}{l}\text { Independent Variables } \\
\text { (continued): }\end{array}$ & $\begin{array}{c}\text { Narrow } \\
(3) \\
\text { rank }\end{array}$ & $\begin{array}{l}\text { Broad } \\
(4) \\
\text { rank }\end{array}$ \\
\hline Institutions* $z_{i}^{n} *$ Pure & $0.209 * * *$ & $0.173^{* * *}$ & Institutions* $z_{i}^{n} * N_{r t} *$ Pure & 0.009 & 0.026 \\
\hline Assembly*Domestic & $(0.07)$ & $(0.06)$ & Assembly*Domestic & $(0.01)$ & (0.019) \\
\hline Institutions* $z_{i}^{n} *$ Pure & $0.203 * * *$ & $0.009 * *$ & Institutions* $z_{i}^{n} * N_{r t} *$ Pure & $-0.024 * * *$ & $-0.040 *$ \\
\hline Assembly*Joint Venture & $(0.07)$ & $(0.05)$ & Assembly*Joint Venture & $(0.01)$ & $(0.022)$ \\
\hline Institutions* $z_{i}^{n} *$ Pure & $0.200 * * *$ & $0.113 * * *$ & Institutions* $Z_{i}^{n} * N_{r t} *$ Pure & $-0.026 * * *$ & $-0.043^{* *}$ \\
\hline Assembly*Foreign & $(0.07)$ & $(0.03)$ & Assembly*Foreign & $(0.01)$ & (0.019) \\
\hline Institutions* $z_{i}^{n} *$ Import & $0.160 * * *$ & $0.188^{* * *}$ & Institutions $* Z_{i}^{n} * N_{r t}{ }^{*}$ Import & $0.014^{*}$ & 0.030 \\
\hline \& Assembly*Domestic & $(0.07)$ & $(0.09)$ & \& Assembly*Domestic & $(0.01)$ & $(0.020)$ \\
\hline Institutions* $z_{i}^{n} *$ Import & $0.458^{* * *}$ & $0.336 * * *$ & Institutions $Z_{i}^{n} * N_{r t}{ }^{*}$ Import & -0.012 & -0.002 \\
\hline \& Assembly*Joint Venture & $(0.07)$ & $(0.06)$ & \& Assembly*Joint Venture & $(0.01)$ & $(0.017)$ \\
\hline Institutions* $z_{i}^{n} *$ Import & $0.608^{* * *}$ & $0.547 * * *$ & Institutions* $Z_{i}^{n} * N_{r t} *$ Import & -0.008 & $-0.026 *$ \\
\hline \& Assembly*Foreign & $(0.07)$ & $(0.08)$ & \& Assembly*Foreign & $(0.01)$ & $(0.016)$ \\
\hline Institutions* $z_{i}^{n} *$ & $0.210^{* * *}$ & $0.101^{* * *}$ & Institutions* $z_{i}^{n} * N_{r t} *$ & 0.008 & -0.012 \\
\hline Ordinary*Domestic & $(0.07)$ & $(0.03)$ & Ordinary*Domestic & $(0.01)$ & $(0.017)$ \\
\hline Institutions* $z_{i}^{n} *$ & $0.506 * * *$ & $0.394^{* * *}$ & Institutions* $Z_{i}^{n} * N_{r t}^{*}$ & -0.011 & 0.016 \\
\hline Ordinary*Joint Venture & $(0.06)$ & $(0.07)$ & Ordinary*Joint Venture & $(0.01)$ & $(0.020)$ \\
\hline Institutions* $z_{i}^{n} *$ & $0.549 * * *$ & $0.531^{* * *}$ & Institutions $* z_{i}^{n} * N_{r t} *$ & 0.004 & -0.001 \\
\hline Ordinary*Foreign & $(0.07)$ & $(0.07)$ & Ordinary*Foreign & $(0.01)$ & (0.019) \\
\hline Skill*Labor Intensity & $\begin{array}{c}0.501 * * * \\
(0.13)\end{array}$ & $\begin{array}{c}0.504^{* * *} \\
(0.13)\end{array}$ & & & \\
\hline Capital*Capital Intensity & $\begin{array}{l}-0.22 \\
(1.30)\end{array}$ & $\begin{array}{c}0.24 \\
(1.27)\end{array}$ & & & \\
\hline Province-year fixed effect & yes & yes & & & \\
\hline $\begin{array}{l}\text { Trade type and Ownership } \\
\text { Interactions }\end{array}$ & yes & yes & & & \\
\hline $\begin{array}{l}\text { Institutions, Trade type \& } \\
\text { Ownership Interactions }\end{array}$ & yes & yes & & & \\
\hline Institutions, $z_{i}^{r s}$, Trade type & & & & & \\
\hline \& Ownership Interactions & yes & yes & & & \\
\hline Observations & 38,638 & 38,638 & & & \\
\hline First Stage F-Test & $\mathrm{F}>116$ & $F>46$ & & & \\
\hline
\end{tabular}

Notes: See the notes to Tables 4 and 5. The interactions terms reported in Tables 4 and 5 are included in these regressions but not reported for brevity. For brevity we only report the results obtained using court rank as the institutional variable, but similar results are obtained using court time or court cost. 